\title{
"O YOU LITTLE LOVABLE BEST FRIEND" WRITING FRIENDSHIP IN THE AGE OF ENLIGHTENMENT
}

\author{
TOBIAS HEINRICH \\ University of Kent, Department of Modern Languages
}

Izvleček: Članek se ukvarja z različnimi diskurzivnimi pristopi do fenomena prijateljstva $v$ srednjem 18. stoletju $v$ nemški kulturi. Izhajajoč iz dela Christiana Fürchtegotta Gellerta »Vier und zwanzigste Moralische Vorlesung« (Štiriindvajseto moralno predavanje) vzpostavlja program vrlin, ki ne temelji več na verskih vrednotah, temveč daje prednost razsvetljenemu uтu in želi to idejo uveljaviti v okviru medsebojnih odnosov. V drugem delu prispevek ponazarja odnos med prijateljstvom in pisemsko kulturo 18. stoletja ter osvetljuje prakso in produkte prijateljske komunikacije.

Ključne besede: prijateljstvo, pisma, razsvetljenstvo, romantika, Christian Fürchtegott Gellert, Johann Wilhelm Ludwig Gleim, Johann Wolfgang von Goethe

\begin{abstract}
This article examines the various discursive strands converging within the cult of friendship in mid-eighteenth-century German culture. Following Christian Fürchtegott Gellert's "Vier und zwanzigste Moralische Vorlesung" (Twenty-fourth Moral Lecture), it explores a programme of virtue that no longer follows religious values, but is informed by the enlightened paradigm of reason, and the redeeming of this idea within the framework of interpersonal relationships. The second half of the article investigates the relationship between friendship and the epistolary correspondence culture in the eighteenth century, illuminating the practices and artefacts of friendship communication.
\end{abstract}

Keywords: friendship, letters, Enlightenment, Romanticism, Christian Fürchtegott Gellert, Johann Wilhelm Ludwig Gleim, Johann Wolfgang von Goethe

The topos of the eighteenth century, that is to say the Age of Enlightenment, as the Century of Friendship, has become commonplace within the field of friendship research. It diagnoses a specific prevalence of philosophical and artistic engagement with the concept of friendship, which emerges from the interrelationship between social transformation processes (the emancipation of the bourgeoisie, the decreased importance of corporative and religious ties) and constellations of the history of ideas (the discovery of the individual). ${ }^{1}$ New methods of statistical analyses likewise seem to confirm this finding. The curve reflecting the frequency of the word "friendship" in Google's Ngram Viewer

1 Dülmen, Die Entdeckung des Individuums. 
reveals a pronounced spike between 1750 and 1775: a high point in the discussion on the nature and function of friendship that has not yet again been matched in modern times. ${ }^{2}$ The engagement with friendship in the eighteenth century was in no way limited to written discourse, as is evident from a consideration of visual art or performative rituals of friendship in the daily culture of the educated bourgeoisie. ${ }^{3}$ Both literature and art became mediums for the expressions of friendship, as with Friedrich Gottlieb Klopstock's ode, "Der Zürchersee” (1750) and Johann Wilhelm Ludwig Gleim's portrait collection in his Temple of Friendship (Freundschaftstempel); to mention just two of the most prominent examples. ${ }^{4}$

In what follows I will address the most important discursive strands that converge within the cult of friendship in the mid-eighteenth century. ${ }^{5}$ Following on from Eckhardt Meyer Krentler, whose seminal study on the subject is still relevant today, ${ }^{6}$ the moralphilosophical debate on friendship will be of primary importance. This concerns the realization of a programme of virtue that no longer follows religious values, but is informed by the enlightened paradigm of reason and the redemption of this idea within the framework of interpersonal relationships.

The second half of this article investigates the relationship between friendship and correspondence culture in the eighteenth century in order to address the phenomenon of writing on the topic of friendship with reference to a specific medium or, rather, genrespecific constellation. On one hand it will illustrate the afore-mentioned cultural-historical dynamics through selected examples. On the other hand it will suggest an additional approach that complements the emphasis on idea and discourse formations with a mediahistorical perspective, thus illuminating both the philosophical and poetological basis as well as the practices and artefacts of friendship communication.

\section{The Discourse on Friendship in the Eighteenth Century}

In his "Vier und zwanzigster Moralischen Vorlesung" (Twenty-fourth Moral Lecture) Christian Fürchtegott Gellert addresses kinship and friendship as the two essential models by which humans are bound and reciprocally obligated to care for each other. ${ }^{7}$ But whereas the bonds of kinship are fixed by nature, friendship is substantially a work of our own choice. ${ }^{8}$ This assessment - perhaps trivial at first glance - strikingly illustrates the

2 https://books.google.com/ngrams/graph?content=Freundschaft\&year_start=1700\&year_end $=2000 \&$ corpus $=20 \&$ smoothing $=3 \&$ share $=\&$ direct_url $=t 1 \% 3 \mathrm{~B} \% 2 \mathrm{CFreundschaft} \% 3 \mathrm{~B} \% 2 \mathrm{Cc} 0$ (Accessed: 16.11.2018).

3 Arburg, "Das Kunstwerk als Freund"; Manger, "Rituale der Freundschaft".

4 Scholke, Der Freundschaftstempel im Gleimhaus.

5 In large part the following article is based on Heinrich, "Tugendempfindsamkeit und Warencharakter". Unless otherwise stated, all translations are by Margarethe Satorius and Tobias Heinrich.

6 Meyer-Krentler, Der Bürger als Freund.

7 Gellert, "Vier und zwanzigste Vorlesung", 254.

8 Ibid., 256. 
turning point of the eighteenth century as regards the societal practices of socialization. Whereas in earlier times, from birth onwards, the individual was bound within a rigid social network that clearly identified the scope of one's development by reference to the cornerstones of occupation, social class and sex, as well as to familial and religious affiliation, in the age of Enlightenment these restrictions slowly began to loosen. The upshot of this was that, for the first time, social relations could be established predominantly on the basis of personal choice and the inclination of individuals towards each other. That our social circles are to some extent the result of our own decision and not determined merely by the circumstances of our class and family ties becomes one of the prerequisites of the modern concept of friendship. When, for instance, friendship is mentioned in the seventeenth century, it does not necessarily connote a relationship that emerges from the expression of individual attraction. Rather, it may be assumed that what is meant is a pragmatic, purpose- and utility-oriented alliance, which should most probably be understood in the spirit of an unwritten pact of solidarity between people of a similar origin. ${ }^{9}$

Such a relationship - one which is founded above all on mutual advantage - is not what Gellert is referring to when he speaks about friendship. In the spirit of Aristotle, who, in his Nicomachian Ethics, differentiates between friendship of utility and friendship of nature, Gellert finally comes to speak about a friendship in which one's counterpart is appreciated for what he or she is, rather than for a benefit that he or she can provide. Gellert perceives this kind of friendship in situations where we recognize ourselves in the other; hence in situations invoking the principle of similarity. Over and above the utility that results from friendship and the character of the friend, Aristotle claims that friendship can also arise from desire and the pleasure that such a relationship brings. This is where Gellert begins to explain the principle of virtue friendship, which is ultimately the subject of his lecture. According to Gellert, the fact that one looks for similarities to one's own self in one's friend as a kind of alter ego must ultimately be understood as a phenomenon of self-love, and is therefore based on natural impulse and not on the free choice of the individual. ${ }^{10}$ True friends love above all those characteristics in their counterparts by which the friends serve as models for each other. According to Gellert, friendship is characterized by a recognition of each other by the persons involved as virtuous, leading them constantly to encourage each other to behave in that way: the love of a sensible friend is the most unmistakable praise for our heart, and his respect "the seal of our integrity."11

Gellert's ideas are representative for his age since they assign the self a significant place in his thinking while at the same time being founded on a bourgeois ethic that cares for the good of society as a whole. Following the enlightened discourse on reasonand virtue-oriented living, the beginning of the eighteenth century had seen the rise of a concept of friendship aimed at mankind as a whole. ${ }^{12}$ Gellert ultimately situates this particular form of "philanthropy", friendship with humankind, as a desirable utopia in

9 Ingen, "Freundschaftskonzepte und literarische Wirkungsstrategien", 173-222.

${ }^{10}$ Gellert, "Vier und zwanzigste Vorlesung", 257.

${ }^{11}$ Ibid., 259.

${ }^{12}$ Meyer-Krentler, Der Bürger als Freund, 29-30. 
Christian moral teachings. ${ }^{13}$ But the special friendship Gellert refers to is not focused on the general idea of humanity: rather, it seeks the proximity of those specific individuals who likewise strive to realize the principle of virtue in their own lives. Now the aspect of friendship that is based on the similarity between friends, which Gellert had previously dismissed as self-love, comes back into play. When the natural drive to seek the connection to people similar to ourselves combines with the pursuit of sincerity and integrity, then - and only then, according to Gellert - will friendship become a valuable vehicle for moral self-perfection.

In so weit also die Freundschaft eine gleichseitige Uebereinstimmung des Charakters und eine von der Natur veranstaltete Aehnlichkeit des Gemüths voraussetzt, in so weit kann sie keine allgemeine Pflicht seyn; und in so weit wir bloß dieser Stimme der Natur, die unsre Herzen einander zuführen will, folgen, in so weit ist es noch keine Tugend. [...] Aber wie reizend wird die Freundschaft nicht, wenn sie sich zugleich auf Natur und auf Tugend gründet! [...] Die wahre Freundschaft ist die gegenseitige Hochachtung und Neigung tugendhafter Gemüther, welche durch die Übereinstimmung ihrer Neigungen Vortheile und Absichten, die in beiden durchgehends aufrichtig und edel seyn sollen, genauer mit einander vereiniget werden. ${ }^{14}$

Therefore, in as far as friendship requires a mutual conformity of character and a similarity of disposition determined by nature, it can not be a general duty; and in as far as we merely follow this voice of nature that leads our hearts to each other, it cannot be a virtue. [...] But how appealing does friendship become, when it is founded at the same time on both nature and virtue! [...] True friendship is the mutual respect and inclination toward virtuous dispositions, which, through the conformity of their inclinations, advantages and intentions (which in both should be consistently sincere and noble) are more truly reconciled.

While, in his remarks on friendship, Gellert primarily conceptualizes a two-member constellation, the friendship experience of his time does not limit itself to the principle of duality. On the contrary: in philosophical, literary and political circles, intellectual and artistic exchange was cultivated across social boundaries. "Geselligkeit" (conviviality/ sociability) was, alongside friendship, the guiding social principle of the age. ${ }^{15}$ The diverse variants of sociability familiar to the eighteenth century are pre-formed by the religious conceptions of Pietism and the communication practices of the Republic of Letters. ${ }^{16}$ The mutual guidance toward virtuous behaviour based on meticulous self-observation links Gellert's idea of friendship with Pietism and its principles of dialogue and common prayer. In the form of piety expressed in continuous communication, ${ }^{17}$ an edifying exchange between believers constitutes the foundation of the Protestant reform movement. The friendship cult of the Enlightenment era can accordingly be seen as a secular continuation of this tradition. At the same time, the eighteenth century also underwent an expansion and

${ }^{13}$ Gellert, "Vier und zwanzigste Vorlesung", 257-258.

${ }^{14}$ Ibid., 258.

15 Adam, "Freundschaft und Geselligkeit", 9-34.

${ }^{16}$ Drawing on the observations of Graubner, "Freundschaft als Konkurrenz", 215.

${ }^{17}$ Gleixner, Pietismus und Bürgertum, 76. 
transformation of the Republic of Letters, that, prior to this point, had mainly served the exchange of ideas among academics. It was in the Age of Enlightenment that the learned discourse of the Early Modern became increasingly differentiated into individual academic disciplines. However, the all-embracing claim of the Republic of Letters lived on in the social practices of the Enlightenment: in friendly conversation, in written correspondence or, more formally, within the framework of printed journals. Thus friendship denotes not just a moral but also a communicative constellation. ${ }^{18}$

Whereas the mid-eighteenth century was the heyday of social friendship practices and the theoretical as well as artistic discourse that arose in conjunction with it, the transition into the nineteenth century is commonly associated with a deterioration of friendship culture. For Hegel, to take one instance, the friendship ideal of the Enlightenment merely paved the way for the self-realization of the subject as an individual: reflection of oneself in another is the precursor of self-awareness. ${ }^{19}$ In opposition to Hegel's perspective, Siegfried Kracauer later laments that the modern social structure had deprived the idea of virtue friendship (in the eighteenth-century sense) of its fertile breeding ground. ${ }^{20}$ Rather, life is permeated with connections that, for Kracauer, can be categorized into acquaintanceship, camaraderie and confraternity. These, however, remain restricted to a finite realm of existence and therefore do not fulfil the need for "total devotion" and "merging together" comprised in the Enlightenment ideal of the unity between virtuous friends. ${ }^{21}$ Meyer-Krentler supplements the afore-mentioned positions held by Hegel and Kracauer in his postulation of a third, according to which the ideal of sociability in the mid-eighteenth century can be viewed as an already atrophied stage of social conceptions existing in the early Enlightenment. In this perspective, friendship is an attempt to realize the aspiration of a social order of virtue on a smaller scale. ${ }^{22}$ Despite their differing perspectives, all three positions agree that the friendship culture of the mid-eighteenth century needs to be regarded as a transient phenomenon. As a historical reference point, however, it remains compatible with culture-critical positions of later eras, particularly when articulating the dilemma of the isolation of the modern individual and its relationship to a social order perceived as anonymous and alienating. ${ }^{23}$

${ }^{18}$ Bosse, "Die gelehrte Republik", 51-76.

${ }^{19}$ Hegel, "Vorlesungen über die Ästhetik II", 190-191.

${ }^{20}$ Kracauer, "Gedanken über Freundschaft", 332-333.

${ }^{21}$ Kracauer, "Über die Freundschaft", 39.

${ }^{22}$ Meyer-Krentler, Der Bürger als Freund, 71.

${ }^{23}$ Ibid., 69-71. The inherent problem of socio-critical reference to a backward-oriented, utopian concept of friendship in the eighteenth century reveals itself when it is drawn upon as a foreshadowing of a totalitarian world view, as is the case in Wolfdietrich Rasch's monograph of 1936, which, on account of its pioneering position within the field of German-language friendship research, still counts among its fundamental works. This despite the fact that in the conceptualization of its subject matter, the study reveals clear affinities to the rampant ethno-national ideology of its period of origin. Rasch, Freundschaftskult und Freundschaftsdichtung. See also the critical analysis in Adam, "Wieder Gelesen", 41-55. 


\section{Friendship and Correspondence Culture in the eighteenth Century}

Precisely the lack of an institutional framework that often makes it difficult to define where friendship begins and ends is what refers us back to its performative character. Friendship as a category of social relationship cannot be conceived of as independent from its underlying practices. Being friends entails a constant activity manifested in specific forms of friendship communication, but also in non-written or non-linguistic practices. In cases where friendship has to be preserved across temporal or spatial distance, the question of its constitution through mediums of communication comes into play. In this context one must not only ask which types of friendship find an expression in mediated form, but also, conversely, how the character of friendship is affected by the possibility of its transmission through the contemporary media. Thus for the eighteenth century Georg Steinhausen has established a parallelism between the cultural history of friendship and the mediatic history of the letter. ${ }^{24}$ Steinhausen argues that the transformation of epistolary conventions is driven by societal upheavals in the Age of Enlightenment. Conversely, the establishment of a comprehensive culture of the written word ${ }^{25}$ in the eighteenth century is the precondition of friendship as a form of mutual self-revelation (as described in relevant treatises by Gellert and others). ${ }^{26}$

The following examples taken from the period 1741-1774 represent a special form of letter, to the extent that all five were intended by their authors for publication, thereby aiming at an audience beyond their direct addressees. In the conscious staging of epistolary friendship communication these texts can thus be read as commentary - or rather, reflection - on relevant discourse and practice. An instructive character is inherent in all of the chosen letters. They take up a position on the issue of what it means to communicate between friends, but consequently also on what it means to be a friend.

The first example comes from the 1741 edition of Heinrich Volck von Wertheim's letter manual Auf neue Manier abgefassten und allzeit fertigen Brief-Steller (Newly Conceived and at all Times Handy Guide to Letter-Writing). This collection of sample letters, which had appeared from 1711 onwards in a series of editions and was published in its present version by Bernhard Dietrich von Scharffenberg, continues to orient itself towards the pompous writing style of the baroque tradition. In their linguistic design the letters appear rigid and formulaic, marked by a legal, ceremonial tone that reflects the hierarchical social structure of class order. ${ }^{27}$ In that sense the following text - found in the section "Assorted Letters" - situates itself within a courtly milieu. The unnamed friend to whom the letter is addressed has recently received a salaried position at a princely court and, following the obligatory congratulations, is requested by the author to sound out the possibilities of finding a similar position for himself.

\footnotetext{
${ }^{24}$ Steinhausen, Geschichte des deutschen Briefs, 307.

${ }^{25}$ Koschorke, Körperströme und Schriftverkehr, 169-185.

${ }^{26}$ See Maurer, "Freundschaftsbriefe - Brieffreundschaften", 76-77.

${ }^{27}$ See Nickisch, Die Stilprinzipien in den deutschen Briefstellern, 150-153.
} 


\begin{abstract}
Hochgeehrter Herr,
Vornehmer Freund,

Mir ist die angenehme Zeitung gebracht worden, dass mein Hochgeehrter Herr unlängst an dem N. Hofe sein Glück gemacht, und wohl recommendiret worden sey; dannenhero von Hertzen dazu gratulire, und wünsche, dass durch die göttliche Gnade Derselbe bey beständiger Gesundheit zu der gnädigen Herrschafft hohen Vergnügen und seiner Hochwerthen Familie [bleibe] [...]. Sollte mein Hochgeehrter Herr eine Gelegenheit sehen, mich bey Seinen Patronen gleichfalls bestens zu recommendiren, damit durch deren Vorschub auch eine Beförderung erhalten möchte; So erbiethe mich zu aller Erkänntlichkeit, und bliebe mir mein Hochgeneigter Gönner nur im Vertrauen zu melden, auf was Weise man dieselben am besten gewinnen könne. ${ }^{28}$
\end{abstract}

\title{
My Most Esteemed Sir, \\ Noble Friend,
}

I have received the pleasant news that my Highly Honourable Gentleman has recently made his fortune at the court of $\mathrm{N}$ and was well recommended. On this occasion, I congratulate him from the heart, and wish that the divine mercy shall keep him in good health to the great pleasure of His Lordship and his noble family. [...] Should my Highly Honourable Gentleman see an opportunity to recommend me to his patrons in a similar manner, so that I, too, might receive a promotion through their support, I offer the most heartfelt gratitude, and it only remains to my kind benefactor to tell me in confidence how one could best gain the same.

Clearly, a concept of friendship is being invoked here that feeds on a goal-oriented calculus. The letter serves as the constitution or, rather, activation of a network of patronage. Friendship here designates a form of relationship in which the persons involved are obliged to give one another support and assistance. ${ }^{29}$ From a social perspective such connections contribute to the embedding and safeguarding of the individual within the social framework of class order. In circumstances where an individual sees himself at the mercy of a rigid, hierarchically structured social order he can at the same time take advantage of the stabilizing effect of reciprocal social connections within his own milieu. Thus we are dealing with a concept of friendship that depends less on subjective inclination than on social decorum. Over and above familial and confraternal connections the friendship network offers the possibility of mutual support on a non-institutional basis. In this context Nacim Ghanbari calls our attention to the ritualistic character of such relationships, ${ }^{30}$ which is directly reflected in the consideration of normative models of friendship communication within a collection of sample letters such as the afore-mentioned guide to letter writing. As is evident in structure and content, the friendship correspondence in the case of the cited sample letter does not centre on the individual condition of the correspondents, but, rather, on the improvement of their respective social and economic status. The designation of the counterpart as "Freund" (friend), especially in the light of the contrast this word makes with his respectful prior salutation as "hochgeehrter Herr" (esteemed Sir), is the cue giving the author freedom to express his request. Friendship becomes a breeding

${ }^{28}$ Wertheim, Auf neue Manier abgefaßter, 198.

${ }^{29}$ Adam, "Freundschaft und Geselligkeit", 7.

${ }^{30}$ Ghanbari, "Netzwerktheorie und Aufklärungsforschung", 320. 
ground for the realization of the patronage relationship, and the letter is its vehicle..$^{31}$ It forms the unspoken background, the a priori, on the basis of which the relationship of the petitioner can be understood by his correspondence partner as reciprocal. The salutation is a consent that requires no further explanation and crystallizes in the utterance of a single word: friend.

Only five years later there appeared a completely differently oriented collection of letters where, for the first time, friendship represents not merely one of many but, rather, the central purpose of epistolary communication: the anonymously published Freundschaftliche Briefe (Friendly Letters), whose authors and publishers were well-known personalities operating within the circle of Halle's first and second schools of poetry, who included Samuel Gotthold Lange, Johann Wilhelm Ludwig Gleim and Johann Georg Sulzer. Freundschaftliche Briefe additionally follows a didactic programme. Letters should now serve the practice of those social skills considered by the publisher to be essential for practised friendship. To these belong both virtuous comportment manifested in tenderness, loyalty and integrity and intellectual faculties such as reason, wit and vivacity of spirit. ${ }^{32}$ Also inseparably linked to both is a specific rhetoric of friendship opposed to the stylistic ideal of a common guide to letter writing. The "language of coercion and flattery" should be replaced by a "language of the heart and confidentiality". ${ }^{33}$ A baroque concept of dissimulation and disguise - of the deliberate staging of emotional sensitivities - is juxtaposed with an ideal of authentic speech predictive of sensitivity and romance. ${ }^{34}$ As in Gellert's statements concerning friendship, we see here the centrality of mutual recognition as virtuous individuals:

\begin{abstract}
Mein Herr,
Meine wahre Freundschaft und unveränderliche Hochachtung zeigt mir alle Augenblikk ihr Bild. Ich sehe Weltweisheit, Tugend, Freundschaft, aufgeräumtes Wesen, und sinnreichen Scherz, und wenn ich dieses zusammen halte, so sehe ich sie. Und dann rede ich von ihnen, und dann will ich an sie schreiben, dann lese ich die Oden des Horaz an seine Freunde, dann mache ich eine an sie. Also komt ein Brief und eine Ode, wie ietzo. ${ }^{35}$
\end{abstract}

Sir,

At every moment the picture of yourself presents me with my true friendship and unchanging respect. I see worldly wisdom, virtue, friendship, orderly character and ingenious jest, and when I bind these together, I see you. And then I speak of you, and then I wish to write to you, and then I read Horace's odes to his friends, and then I write one for you. From this comes a letter and an ode, as you see now.

That fact that already in the first letter of the collection an insight into the moral

${ }^{31}$ On the mediality of patronage, especially the role of letters of recommendation, see Jost, "Eintrittskarte ins Netzwerk", 103-143; Ghanbari, "Netzwerktheorie und Aufklärungsforschung", 321-322.

${ }^{32}$ Gleim, introduction to Freundschaftliche Briefe, [12].

${ }^{33}$ Ibid., [13].

${ }^{34}$ Pompe, "Natürlichkeitsideal", 183-203.

${ }^{35}$ Gleim, Freundschaftliche Briefe, 1. 
character of the author's friend is conveyed through his visual appearance is one that is not insignificant in relation to Gleim's portrait collection. At the same time, the sight of the counterpart and his moral character inspires writing and reading. Thus friendship is experienced as a transmitted relationship on multiple mediatic and artistic levels.

While research has only recently come to an adequate appreciation of the epochal role of the Freundschaftliche Briefe within German-speaking epistolary rhetoric ${ }^{36}$ the paradigm shift achieved therein is more generally associated with Gellert's Praktische Abhandlung von dem guten Geschmacke in Briefen (Practical Treatise on Good Taste in Letters), published in 1751. Alongside naturalness of expression and a rejection of the stereotypical nature of the German letter-writing tradition, Gellert emphasizes the representative function of epistolary correspondence. The letter should assume the role of oral conversation. This is also accompanied by a redefinition of the relationship between friendship and epistolary poetics, which had already been indicated in the Freundschaftiche Briefe. Particularly telling is the first, thus programmatic, entry in the sample letter collection that Gellert added to his treatise:

An den Herrn Rittmeister von $\mathrm{B}^{* * * *}$.

Es ist wahr, meine Briefe an Sie enthalten beynahe einerley; immer Versicherungen, dass ich Sie von Herzen liebe, dass ich Sie hoch schätze; immer Danksagungen und gute Wünsche. Aber was kann ich dafür? Liebte ich Sie weniger, und wären Sie nicht so redlich gegen mich gesinnt: so würde ich nicht beständig von Ihnen und von meiner Ergebenheit reden können. So lange Sie also Ihr Herz gegen mich nicht ändern, (und wie könnten Sie das?) so stehen Sie beständig in der Gefahr einerley Briefe von mir zu lesen. Doch was schadets? Können die Verliebten in ihren Briefen, ohne es überdrüssig zu werden, von nichts, als von Liebe, reden: so müssen auch gute Freunde von der Freundschaft reden können, ohne dabey müde zu werden. Mögen doch andre ihre Blätter mit täglichen Neuigkeiten anfüllen, wir wollen sie mit den Empfindungen unsers Herzens anfangen und beschließen. Es ist für mich eine Sache von der größten Wichtigkeit, Ihr Freund zu seyn, und ich fühle so viel Vergnügen dabey, wenn ichs Ihnen sage, dass ichs Ihnen ganz gewiß noch viel hundertmal sagen werde. Leben Sie wohl, und lieben Sie mich. ${ }^{37}$

To Mr. Rittmeister von $\mathrm{B}^{* * * *}$.

It is true, my letters to you nearly all contain the same; always assurances that I love you from the heart, that I value you highly; always expressions of thanks and good wishes. But what can I do? Were I to love you less, and were you not so openly ill-disposed towards me, I could not speak constantly of you and my devotion. As long as you do not change the adverse inclination of your heart towards me, (and how could you do that?), you are in constant danger of reading letters of the same kind from me. But what harm does this do? If the lovers in your letters can speak of nothing but love without becoming weary, so, too, must good friends speak of friendship without tiring of it. While others may like to fill your pages with daily news, we wish to start and conclude them with the sensations of our heart. For me it is a matter of the highest importance to be your friend, and I feel such pleasure in telling you that I will surely tell you many hundreds of times more. Fare well, and love me.

${ }^{36}$ Hentschel, "'Besuche in Briefen"”, 183-200; Ahrens, "Die Freundschaftlichen Briefe", 48-69.

${ }^{37}$ Gellert, "Briefe, nebst einer praktischen Abhandlung", 150. 
In contrast to the cited example from Volck von Wertheim's guide to letter-writing, friendship does not appear here in any way purpose-oriented. On the contrary: the ironic game played with incongruous terms from the language of love may be explained precisely by the letter's seeming lack of content. ${ }^{38}$ The author has nothing more to say than to assure the addressee verbosely of his deepest affinity. The friendly relationship is therefore not a mere point of departure for communication: rather, this letter is also intended as its expression and confirmation. The letter is a performative consummation of friendship.

Like the Freundschaftliche Briefe, the next text originates from a publication of which Johann Wilhelm Ludwig Gleim was a joint author. In contrast to the anonymously published collection of letters of 1746, the names of both authors appear prominently on the title page of this volume (1768): Briefe von den Herren Gleim und Jacobi (Letters from Messrs. Gleim and Jacobi). The preface invents a further, fictitious publisher who has appropriated the letters in order to publish them without the other persons' knowledge. Admittedly, this device merely preserves the appearance of modesty, a scruple that would ordinarily prohibit the shameless self-advertisement undertaken by the two correspondents. But of particular interest in conjunction with our topic is the representation of friendship through the medium of print, as shown in a letter from the afore-mentioned collection dated 17 September 1767:

Der Kutscher kam diesen Morgen zurück, welche Freude! von meinem Jacobi bringt er mir gewiß zween Zeilen mit. Aber nicht eine trug er in der Hand. [...] Keines von dem Herrn Professor? Nein, sagt er, selbst halb unzufrieden daß er keines hatte; denn er sah es dem Fragen wohl an, daß er billig eins haben sollte. Itzt gegen Mittag bringt mir der Briefträger ein dickes Päckchen, die Aufschrift von einer fremden Hand, und darinn ein Buch! ein Buch? Von wem? Wer könnte mir wohl ein Buch senden? Gold könnten mir zehne senden; aber Bücher, wer macht sich etwas aus Büchern? Aufgerissen wurde das Päckchen, und, o welch ein süßer Anblick! eine Zeile von der Hand meines Jacobi, zehn Zeilen, zwanzig, dreyßig, wer kann sie zählen? Gelesen, empfunden, gepriesen wurden sie; und dann geküßet, wie ein Liebhaber in der süßesten Entzückung seiner Liebe sein Mädchen küßet - - Die Nichte kam dazu; was küßen sie denn da, Herr Onkel, und mit ihrer langsamsten Rede, wurde gefraget, und geantwortet: Meinen Jacobi! O Sie kleiner liebenswürdiger bester Freund! ${ }^{39}$

The coachman returned this morning. What a joy! From my Jacobi he is certainly bringing me two lines. But not one did he carry in his hand. [...] None from the professor? No, he says, himself half dissatisfied that he had none, because he perceived from the interrogation that he should properly have one. Now, towards noon, the postman brings me a thick parcel labelled by a hand unknown to me, and therein a book! A book? By whom? Who could be sending me a book? Tens of people could send me gold; but books, who cares for books? The package was ripped open, and, o what a sweet sight! a line from my Jacobi's hand, ten lines, twenty, thirty, who can count them? Read, felt, praised they were; and then kissed, as a lover in the sweetest joy of his love kisses his girl. - - The niece came by: What are you kissing there, my uncle? And in her slowest diction this question was asked, and answered with: My Jacobi! O you little, lovable best friend!

${ }^{38}$ On this subject in greater detail, see Vellusig, Schriftliche Gespräche, 106.

${ }^{39}$ Gleim and Jacobi, Briefe von den Herren Gleim und Jacobi, 23-24. 
In this short episode as described by Gleim friendship is no longer comprehensible as a simple immaterial social or, rather, communicational relationship. The printed book, probably a literary anthology edited by Karl Wilhelm Ramler including a poem by Jacobi, and, most important, the accompanying handwritten lines, become a concrete symbol of friendship. The caresses that Gleim bestows on Jacobi's letter sublimate the homoerotic desire between the two correspondents. The cited passage thereby attests to a sociodynamic model that shaped the discourse of both love and friendship in the eighteenth century. The body of the text, here duplicated in the twin forms of a handwritten letter and a printed book, becomes a fetish through its play on an absent presence. Writing becomes an object of desire, and in so doing takes the place of its physical counterpart, who cannot be present in the same manner on account of spatial distance; but on whom, in the context of contemporary corporeal morals, the caresses described can be bestowed only in imaginary, not real, guise. ${ }^{40}$

This representation of a friendship in which even physical tenderness plays such an incisive role earned a mixed reception amongst contemporaries. Whereas the published letters certainly achieved success among their anonymous readership, judgement was less kind in the inner circle of literary Germany. It was not so much the tone that garnered disapproval, but, rather, the calculated posture taken up by the correspondents that belied the ostensibly non-purpose-oriented character of their friendship. On this point, a review in the Allgemeine Deutsche Bibliothek (Universal German Library) is revealing: "Wir glauben zuweilen nicht zwey für einander brennende Herzen, sondern zwey kaltblutige Leute zu hören, die sich heiser geschryen, und sich in frostigen Hyperbeln und leeren Ausrufungen erschöpfen. ". ${ }^{41}$ (At times we believe that we are hearing not two hearts burning for each other but, rather, two cold-blooded men screaming hoarsely and exhausting themselves in frosty hyperboles and empty proclamations.) It is a fair assumption that the correspondents were concerned mainly with establishing a name within the public literary sphere for the young writer and unsalaried professor of philosophy at the University of Halle through this exchange with an established poet, Gleim. This belief receives support from the observation that the style of correspondence quite deliberately follows that of the letters exchanged in the Anacreontic circle of lyric poets, which were stylistically seminal for the Freundschaftlichen Briefe. Thus, friendship is not only carried out performatively, but also serves as a means of inscribing oneself in an existing discourse through strategic emulation and the calculated selection of one's interlocutor.

Our last example is perhaps also the best-known: the enactment of friendship in the most canonical of German epistolary novels: Goethe's Die Leiden des jungen Werthers (The Sorrows of Young Werther) (1774). It is not the ambivalent adversarial friendship between Werther and Albert we would like to discuss but, rather, the relationship between the protagonist and the recipient of his letters, Wilhelm. Cited below is the beginning of the first letter, since it is exemplary for the novel as a whole:

${ }^{40}$ Cf. Koschorke, Körperströme und Schriftverkehr, 154-162. On the topic of homoeroticism in the letters of Gleim, see Mohr, "'Freundschaftliche Briefe", 14-75; Richter, "Ins and Outs of Intimacy", 111-124; Richter, "Winckelmann's Progeny", 33-46; Wilson, "But is it Gay?", 767-783.

${ }^{41}$ Anonymous, "Briefe von Herrn Gleim und Jacobi", 189-194. 
Wie froh bin ich, daß ich weg bin! Bester Freund, was ist das Herz des Menschen! Dich $\mathrm{zu}$ verlassen, den ich so liebe, von dem ich unzertrennlich war, und froh zu sein! Ich weiß, du verzeihst mir's. Waren nicht meine übrigen Verbindungen recht ausgesucht vom Schicksal, um ein Herz wie das meine zu ängstigen? Die arme Leonore! Und doch war ich unschuldig. Konnt' ich dafür, daß, während die eigensinnigen Reize ihrer Schwester mir eine angenehme Unterhaltung verschafften, daß eine Leidenschaft in dem armen Herzen sich bildete? Und doch - bin ich ganz unschuldig? Hab' ich nicht ihre Empfindungen genährt? Hab' ich mich nicht an den ganz wahren Ausdrücken der Natur, die uns so oft zu lachen machten, so wenig lächerlich sie waren, selbst ergetzt? Hab' ich nicht - o was ist der Mensch, daß er über sich klagen darf! Ich will, lieber Freund, ich verspreche dir's, ich will mich bessern $\left[\ldots . .{ }^{42}\right.$

How happy I am to be away! My dear friend, what a thing is the heart of Man! To leave you, whom I love so, from whom I was inseparable, and to be happy! I know that you will forgive me. Were not my other attachments hand-picked by Fate to beset a heart such as mine with fears? Poor Leonore! And yet I was innocent. Was it my fault that, while I was taking pleasure and amusement in the wilful charms of her sister, a passion was growing in that poor heart? And yet - am I wholly innocent? Did I not nurture her feelings? Did I not take delight in those utterly true expressions of her nature which so often made us laugh, though they were far from ridiculous? Did I not - Oh, what a creature is Man, that he may bewail himself! I promise, dear friend, I promise I shall improve $[\ldots]^{43}$

Alongside the central theme of the book, love, the topic of friendship is given coequal importance. Of all of the selected examples, and in the most fictitious of them, the revelatory character of friendship becomes most apparent. Indeed, the epistolary novel, for the dissemination of which in the German-speaking world Gellert played no small role with his Leben der Schwedischen Gräfin von $G^{* * *}$ (Life of the Swedish Countess of $\left.\mathrm{G}^{* * *}\right)(1747 / 48)$, derives its appeal not least from its introspection into the thoughts and feelings of the characters as facilitated by the medium of the letter. What we know of Werther is imparted to us through the prism of friendship. Goethe, unlike the authors of the overwhelming majority of contemporary epistolary novels, has decided to develop the plot (with the exception of the final passage) solely from the perspective of the protagonist. Wilhelm's written responses to Werther are not included. All that can be said about the mute counterpart of the main character has to be reconstructed from the utterances of Werther. The dialogical, conversational character that, for Gellert, still constituted the essence of a good letter becomes reduced here to a monologue.

Notwithstanding this, in the void left by the lack of written response a significant opportunity arises: the opportunity for the reader to take Wilhelm's place. This is already reflected in the emphatic mode of address used in the novel, but also in the preface, where the author recommends the book to his reader as a friend. ${ }^{44}$ The narrative fixation on the eponymous protagonist acts as the communicative preparation of the text for the reader. Consequently, this can be viewed as a foretaste of Romanticism in which literature

${ }^{42}$ Goethe, Werke, 7.

${ }^{43}$ Trans. Michael Hulse.

${ }^{44}$ Mellmann, "Das Buch als Freund", 201-240. 
conceals the anonymous mass character of the printed book in an intimate gesture of self-expression. ${ }^{45}$ In a situation where the real-world author and reader increasingly face one another as strangers, the literary text comes across as a discourse between friends, seemingly guaranteeing the highest degree of familiarity and individuality in the written text. It is precisely in Wilhelm's silence that the reader is enabled to take over his role and imagine that Werther's letters are directed towards - and exclusively towards - him. Just as the Freundschaftliche Briefe in 1744 and Gellert's Abhandlung seek to combine the emerging culture of letter-writing with the contemporaneous ideal of virtue friendship, Gleim, Jacobi and especially Goethe, writing in the second half of the century, react in their literary conceptions of friendship to the book market as a mass phenomenon. Friendship correspondence thereby becomes a commodity that can be printed, sold and consumed through reading. In this way, the edifying character of virtue friendship survives, although it becomes a one-sided, monological experience for the reader. Friendship relationships formed by readers with real or fictional literary characters become a simulacrum, and thereby a mirror, though also a substitute for social relationships in which both relationship partners are accorded a voice. Thus we may perceive, embedded in the literary correspondence culture of the Enlightenment era, a link between this imaginary friendship and the celebrity culture of our present day.

${ }^{45}$ See Mole, Byron's Romantic Celebrity, 22-25. 


\section{Sources and Bibliography}

\section{SOURCES}

Anonymous. "Briefe von Herrn Gleim und Jacobi, Berlin, 1768". Allgemeine Deutsche Bibliothek 10, no. 1 (1769): 189-194.

Gellert, Christian Fürchtegott. "Briefe, nebst einer praktischen Abhandlung von dem guten Geschmacke in Briefen". In Christian Fürchtegott Gellert: Gesammelte Schriften, edited by Bernd Witte, vol. 4, 272-328. Berlin: Walter de Gruyter, 1989. https://doi. org/10.1515/9783110861341.272.

_. "Vier und zwanzigste Vorlesung: Von den Pflichten der Verwandtschaft und Freundschaft". In Christian Fürchtegott Gellert: Gesammelte Schriften, edited by Bernd Witte, vol. 6, 254-262. Berlin: Walter de Gruyter, 1992.

Gleim, Johann Wilhelm Ludwig. Freundschaftliche Briefe. Berlin: [s.n.], 1746. , and Johann Georg Jacobi. Briefe von den Herren Gleim und Jacobi. Berlin: [s.n.], 1778. Goethe, Johann Wolfgang von. Werke: Hamburger Ausgabe. Vol. 6. Edited by Erich Trunz. München: Deutscher Taschenbuch, 1996.

Hegel, Georg Wilhelm Friedrich. "Vorlesungen über die Ästhetik II". In Georg Wilhelm Friedrich Hegels Werke, vol. 14, edited by Eva Moldenhauer and Karl Markus Michel. Frankfurt am Main: Suhrkamp, 1980.

Wertheim, Heinrich Volck von. Auf neue Manier abgefaßter und allzeit fertiger Brief-Steller [...]. Edited by Bernhard Dietrich von Scharffenberg. Chemnitz: Joh. Christoph und Joh. David Stößeln, 1741.

\section{LITERATURE}

Adam, Wolfgang. "Freundschaft und Geselligkeit im 18. Jahrhundert". In Der Freundschaftstempel im Gleimhaus zu Halberstadt: Porträts des 18. Jahrhunderts; Bestandskatalog, edited by Horst Scholke, 9-34. Leipzig: E. A. Seemann, 2000. . "Wieder Gelesen: Wolfdietrich Rasch; Freundschaftskult und Freundschaftsdichtung im deutschen Schrifttum des 18. Jahrhunderts". In Ars et Amicitia: Beiträge zum Thema Freundschaft in Geschichte, Kunst und Literatur; Festschrift für Martin Bircher zum 60. Geburtstag am 3. Juni 1998, edited by Ferdinand van Ingen and Christian Juranek, 41-55. Amsterdam: Rodopi B. V., 1998.

Ahrens, Moritz. "Die Freundschaftlichen Briefe von 1746: ein kooperatives Publikationsprojekt”. Das Achtzehnte Jahrhundert 42, no. 1 (2018): 48-69.

Arburg, Hans-Georg von. "Das Kunstwerk als Freund: eine Leitidee Winckelmanns mit Folgen für die frühe Kunstgeschichte”. In Ars et Amicitia: Beiträge zum Thema Freundschaft in Geschichte, Kunst und Literatur; Festschrift für Martin Bircher zum 60. Geburtstag am 3. Juni 1998, edited by Ferdinand van Ingen and Christian Juranek, 503-533. Amsterdam: Rodopi B. V., 1998.

Bosse, Heinrich. "Die gelehrte Republik". In "Öffentlichkeit” im 18. Jahrhundert, edited by Hans-Wolf Jäger, 51-76. Göttingen: Wallstein, 1997.

Dülmen, Richard van. Die Entdeckung des Individuums: 1500-1800. Frankfurt am Main: Fischer Taschenbuch, 1997. 
Ghanbari, Nacim. "Netzwerktheorie und Aufklärungsforschung”. Internationales Archiv für Sozialgeschichte der deutschen Literatur 38, no. 2 (2013): 315-335. https://doi. org/10.1515/iasl-2013-0014.

Gleixner, Ulrike. Pietismus und Bürgertum: Eine historische Anthropologie der Frömmigkeit. Bürgertum, Neue Folge 2. Göttingen: Vandenhoeck \& Ruprecht, 2005.

Graubner, Hans. "Freundschaft als Konkurrenz im Sturm und Drang: Herder - Hamann, Goethe - Herder". In Dioskuren, Konkurrenten und Zitierende: Paarkonstellationen in Sprache, Kultur und Literatur; Festschrift für Helmut Göbel and Ludger Grenzmann, edited by Jan Cölln and Annegret Middeke, 215-244. Göttingen: Vandenhoeck \& Ruprecht, 2014. https://doi.org/10.14220/9783737003001.215.

Heinrich, Tobias. "Tugendempfindsamkeit und Warencharakter: Freundschaft im 18. Jahrhundert, ihre Konzeptualisierung und ihre Ausgestaltung im gedruckten Brief". In Poetik und Praxis der Freundschaft (1800-1933), edited by Erik Schilling and Andree Michaelis-König, 23-36. Heidelberg: Universitätsverlag Winter 2019.

Hentschel, Uwe. “'Besuche in Briefen': Die epistolare Praxis der Anakreontiker und Gellerts Briefreform”. Orbis Litterarum 56, no. 5 (2001): 378-395. https://doi. org/10.1111/j.0105-7510.2001.oli560505.x.

_. "“Briefe sind Spiegel der Seelen': Epistolare Kultur des 18. Jahrhunderts zwischen Privatheit und Öffentlichkeit”. Lessing Yearbook 33 (2001): 183-200.

Ingen, Ferdinand van. "Freundschaftskonzepte und literarische Wirkungsstrategien im 17. Jahrhundert”. In Ars et Amicitia: Beiträge zum Thema Freundschaft in Geschichte, Kunst und Literatur; Festschrift für Martin Bircher zum 60. Geburtstag am 3. Juni 1998, edited by Ferdinand van Ingen and Christian Juranek, 173-222. Amsterdam: Rodopi B. V., 1998.

Jost, Erdmut. "Eintrittskarte ins Netzwerk: Prolog zu einer Erforschung des Empfehlungsbriefes”. In Briefwechsel: Zur Netzwerkbildung in der Aufklärung, edited by Erdmut Jost and Daniel Fulda, 103-143. Halle an der Saale: Mitteldeutscher Verlag, 2012.

Koschorke, Albrecht. Körperströme und Schriftverkehr: Mediologie des 18. Jahrhunderts. München: Wilhelm Fink, 1999.

Kracauer, Siegfried. "Gedanken über die Freundschaft" [1921]. In Essays, Feuilletons, Rezensionen 1906-1923, edited by Inka Mülder-Bach, 332-350. Siegfried Kracauer Werke 5. Frankfurt am Main: Suhrkamp, 2011.

. "Über die Freundschaft" [1917/18]. In Essays, Feuilletons, Rezensionen 1906-1923, edited by Inka Mülder-Bach, 29-59. Siegfried Kracauer Werke 5. Frankfurt am Main: Suhrkamp, 2011.

Manger, Klaus. "Rituale der Freundschaft: Sonderformen sozialer Kommunikation". In Rituale der Freundschaft, edited by Klaus Manger and Ute Pott, 23-49. Heidelberg: Winter, 2006.

Maurer, Michael. "Freundschaftsbriefe - Brieffreundschaften". In Rituale der Freundschaft, edited by Klaus Manger and Ute Pott, 69-81. Heidelberg: Winter, 2006.

Mellmann, Katja. "Das Buch als Freund - der Freund als Zeugnis: Zur Entstehung eines neuen Paradigmas für Literaturrezeption und persönliche Beziehungen, mit einer Hypothese zur Erstrezeption von Goethes Werther". In Bürgerlichkeit im 18. 
Jahrhundert, edited by Hans-Edwin Friedrich, Fotis Jannidis and Marianne Willems, 201-240. Studien und Texte zur Sozialgeschichte der Literatur 105. Tübingen: De Gruyter, 2006. https://doi.org/10.1515/9783110922370.201.

Meyer-Krentler, Eckhardt. Der Bürger als Freund: Ein sozialethisches Programm und seine Kritik in der neueren deutschen Erzählliteratur. München: Wilhelm Fink, 1984.

Mohr, Heinrich. "'Freundschaftliche Briefe' - Literatur oder Privatsache? Der Streit um Wilhelm Gleims Nachlaß". Jahrbuch des Freien Deutschen Hochstifts (1973): 14-75. Mole, Tom. Byron's Romantic Celebrity: Industrial Culture and the Hermeneutic of Intimacy. Basingstoke: Palgrave Macmillan, 2007. https://doi.org/10.1057/9780230288386.

Nickisch, Reinhard. Die Stilprinzipien in den deutschen Briefstellern des 17. und 18. Jahrhunderts: Mit einer Bibliographie zur Briefschreiblehre (1474-1800). Göttingen: Vandenhoeck \& Ruprecht, 1969.

Pompe, Hedwig. "Natürlichkeitsideal". In Historisches Wörterbuch der Rhetorik, vol. 6, Must-Pop, edited by Gert Ueding, 183-203. Tübingen: Max Niemeyer, 2003.

Rasch, Wolfdietrich. Freundschaftskult und Freundschaftsdichtung im deutschen Schrifttum des 18. Jahrhunderts vom Ausgang des Barock bis zu Klopstock. Halle an der Saale: Max Niemeyer, 1936.

Richter, Simon. "The Ins and Outs of Intimacy: Gender, Epistolary Culture, and the Public Sphere". The German Quarterly 69, no. 2 (1996): 111-124. https://doi. org/10.2307/408336.

_ . "Winckelmann's Progeny: Homosocial Networking in the Eighteenth Century". In Outing Goethe \& His Age, edited by Alice A. Kuzniar, 33-46. Stanford: Stanford University Press, 1996.

Scholke, Horst. Der Freundschaftstempel im Gleimhaus zu Halberstadt: Porträts des 18. Jahrhunderts; Bestandskatalog. Leipzig: E. A. Seemann, 2000.

Steinhausen, Georg. Geschichte des deutschen Briefs: Zur Kulturgeschichte des deutschen Volkes. 2 vols. Berlin: Weidmann, 1891.

Vellusig, Robert Heinz. Schriftliche Gespräche: Briefkultur im 18. Jahrhundert. Wien: Böhlau, 2000.

Wilson, W. Daniel. "But is it Gay? Kissing, Friendship, and 'Pre-Homosexual' Discourse in Eighteenth-Century Germany”. Modern Language Review 103, no. 3 (2008): 767-783. 


\section{»O, TI MALI LJUBEZNIVI NAJBOLJŠI PRIJATELJ«: PRIJATELJSTVO V PISEMSKI KULTURI RAZSVETLJENSTVA}

\section{Povzetek}

Čas razsvetljenstva v študijah o prijateljstvu 18. stoletja velja za »dobo prijateljstva«. Literatura koncept prijateljstva vedno znova asociira s specifično nadvlado filozofskih in umetniških teženj, medtem ko prijateljstvo v tem času velja za rezultat soodvisnosti med procesi družbenega razvoja (emancipacija meščanstva in upad pomena družbenih in verskih vezi) in tedaj veljavnem splošnem nadzoru (odkritje individualnosti). Prispevek se osredotoča na različne diskurzivne pristope do prijateljstva sredi 18. stoletja v nemški kulturi. Christian Fürchtegott Gellert je v svojem spisu »Vier und zwanzigste Moralische Vorlesung« (Štiriindvajseto moralno predavanje) vzpostavil program vrlin, ki ni več izhajal iz verskih vrednot, temveč je v ospredje postavil razsvetljeni um in to idejo poskusil prenesti tudi v medsebojni prijateljski odnos. Gellertove ideje so za čas dejansko reprezentativne, saj avtor sebe postavlja na pomembno mesto, hkrati pa so tudi pomemben dejavnik etičnega nadzora meščanstva, ki je razglabljal o tem, kako se udejstvovati za splošno družbeno dobro.

Drugi del članka opisuje odnos med prijateljstvom in pisemsko kulturo 18. stoletja in osvetljuje epistolarno prakso ter artefakte prijateljske korespondence. Iz analize izbranih objavljenih pisem je mogoče ponazoriti transformacijo ideje o prijateljstvu: od Gellertovega pragmatičnega pristopa, ki v prijateljski zvezi vzpostavlja korist in namen, do prijateljske zveze, ki jo v literaturi eksemplarično zastopata Johann Wilhelm Ludwig Gleim s svojimi objavljenimi pismi ali Johann Wolfgang von Goethe v pisemskem romanu Trpljenje mladega Wertherja. V literarni zasnovi prijateljstva sta se Gleim in Goethe odzvala tudi na knjižni trg kot masovni fenomen. Prijateljska korespondenca je postala produkt, ki ga je mogoče objaviti, prodajati in konzumirati skozi branje. S tem je prijateljstvo za bralca postalo poučna, četudi enostranska vrlina in povsem monološka izkušnja. Prijateljski odnosi, ki si jih je bralec ustvaril na podlagi resničnih ali namišljenih literarnih oseb, so zanj postali navidezno realna podoba in ogledalo odnosov, hkrati pa tudi nadomestek harmoničnih družbenih stikov. Na ta način je v kulturi literarne korespondence razsvetljenstva mogoče videti tudi povezavo imaginarnega prijateljstva z moderno zvezdniško in elitno kulturo današnjega časa. 